\title{
O Assistencialismo na Capitania do Ouro
}

Caio C. Boschi

Universidade Federal de Minas Gerais

Inspirado nos princípios de caridade cristã de ajuda e amparo ao próximo, o assistencialismo, do ponto de vista histórico, desde os seus primórdios, se destacou entre as formas de ação social implementadas, seja por indivíduos, seja por agremiações, seja por organismos públicos ou privados. Assentando-se no sentimento de fraternidade humana, o assistencialismo investe-se de um conteúdo ora paternalista, ora mutualista, não se apresentando como fator de transformação social, mas tão somente como forma de prestação de serviços aos necessitados de proteção $\theta$ apoio, buscando minorar suas agruras ou satisfazer suas necessidades.

Nessa medida, o assistencialismo não se propõe alterar as condições sociais da realidade concreta de um dado momento histórico. E irretorquível a sua conotação ideológica, ou seja, o seu caráter de mantenedor do status quo, ao contrário do moderno Serviço Social. O nível de atuação do assistencialismo se reduz ao âmbito de realidades microssociais, vale dizer, ao atendimento de individualidades, grupos ou comunidades. A caridade, a beneficência e a filantropia - as duas primeiras, formas de assistencialismo de inspiração religiosa; a última, de inspiração laica 
- caracterizam sua atuação pelo imediatismo, na busca de solucionar situações específicas de ajuda aos necessitados. Com isso, as classes dominantes se antecipam ao advento de atitudes e manifestações coletivas contestatórias dos menos favorecidos, agindo em duas frentes: de um lado, atendendo a mendigos, inválidos, velhos e órfãos; de outro, incorporando ao seu trabalho a colaboração da Igreja, particularmente no que diz respeito à legitimação mesma desse trabalho.

Ao fim e ao cabo, o propósito, repita-se, é claro: o exercício dessas políticas assistenciais neutralizava o potencial de ameaça à ordem vi gente, encarnado nas camadas sociais de necessitados e despossuídos.

O assistencialismo, no qual está subjacente, do ponto de vista ideológico, a questão dos comportamentos conformistas, adquire formas e roupagens peculiares às épocas históricas e aos contextos nos quais se insere. E assim que, com o surgimento e o fortalecimento do Estadc Moderno, delineiam-se formas específicas de atividades assistenciais, de que são exemplo as Santas Casas de Misericórdia.

A Baixa Idade Média presenciara o desabrochar de numerosas comunidades fraternais. Enquanto as corporações de ofício atendiam aos interesses profissionais de seus integrantes, as irmandades, de modo especial as Misericórdias, encarregavam-se dos encargos assistenciais e espirituais. Isto não equivale a desconhecer que grande parte das confrarias teve origem nos ofícios, naqueles casos em que o caráter devocional era mais marcante. Não se nega também o mutualismo intergrupal praticado nas corporações, embora de forma mais rígida, porque compulsória. Deve ficar claro, porém, que confraria não era sinônimo de corporação. Quando muito, poderia ser a face religiosa desta última, para não falar de outras diferenças essenciais, como se verifica no caráter mais democrático das fraternidades, nas quais a ocupação profis. sional não era conditio sine qua non para a admissão. Cumprindo basicamente suas obrigações financeiras, o confrade adquiria as benesses e a segurança indispensáveis para os tempos de doença e invalidez e, no extremo, garantia seu próprio sepultamento.

Tomando-se como base essas premissas e voltando-se as vistas para a realidade histórica do império colonial português, há que se pensar sempre em um Estado cuja preocupação quase que exclusiva e obsessiva foi a de preservar o status quo e no qual o denominado terceiro estado devia encontrar soluções próprias para os desafios e para as demandas criadas pela monarquia absoluta que aí se instalara.

Em outras palavras, vale dizer que a assistência social perante $o$ poder em Portugal estava então relegada a segundo plano. O Estado português nascera e se organizara preocupado fundamentalmente com a preservação dos interesses das classes privilegiadas, não entendendo como 
seu dever o provimento de serviços demandados pela sociedade. Assim, desassistidos e desamparados, os segmentos inferiores agruparam-se e desenvolveram formas de auto-preservação. Aos poucos, generalizou-se 0 entendimento de que ao Estado caberia a administração dos negócios públicos, isto é, da economia em geral, ao passo que, à piedade particular $\mathrm{e}$ às associações leigas se confeririam a responsabilidade e o ônus da assistência pública. Em função disso, o propósito da coesão associativa tornou-se o de servir de defesa dos interesses e aspirações comuns, através da prática de um assistencialismo que viesse substituir as manifestações e atos isolados de caridade. Criou-se em Portugal, a partir de então, um traço que marcaria, ao longo dos séculos, a civilização portuguesa: seu caráter mutualista.

Nessa perspectiva e na medida em que se desnvolvia e se fortalecia, o terceiro estado (1) (em especial os mercadores, os negociantes e os mesteirais) procurava ampliar seus canais de manifestação e ocupar novos espaços sociais. Por seu turno, também o Estado redimensionava sua política em relação às associações leigas impondo-lhes uma subordinação mais direta e efetiva. Se bem que desde fins do século XIII já existisse essa subordinação, foi somente dois séculos mais tarde que o Estado português passou a reconhecer, nas confrarias, uma força auxiliar que assegurava as funções públicas e, então, efetivamente voltou suas vistas para o real significado delas. Como resultado, transcendendo o mutualismo fechado das corporações, as irmandades, com o apoio da Igreja e dos monarcas, tornaram-se o instrumento da reforma das atividades assistenciais (2).

A nova política pode ser captada à luz da criação das irmandades das Misericórdias e da concomitante tendência de fusão dos pequenos em grandes hospitais. Ambos os empreendimentos inserem-se no contexto da centralização absolutista implementada nos fins do século XV, notadamente com D. João II, ao mesmo tempo em que passavam a abarcar um universo mais amplo de desamparados, gerado pelo expansionismo marítimo-geográfico a que Portugal se lançara. A monarquia absoluta nesse momento empenhava-se em laicizar a assistência social, com o firme pro-

(1) - Terceiro Estado ou Braço Popular são terminologias utilizadas por Vitorino Magalhães Godinho em sua $A$ Estrutura na Antiga Sociedade Portuguesa (Lisboa, Arcádia, 1971), compreendendo quatro grupos sociais: “a) agricultura (trabalhando quer a terra própria, quer a que têm de mão alheia); b) mercadores e megociantes; c) mesteirais oficiais mecânicos, isto é, os ligados às atividades industriais; d) os que servem a outrem - na agricultura, no comércio ou na indústria (nestes dois ramos, apenas se contam nesta categoria os serviçais não qualificados, os não profissionais propriamente ditos), nos serviços domésticos $\mathrm{e}$ anexos" (op. cit., pp. 82/3).

(2) - Mesgravis, Laima. A Santa Casa de Misericórdia de São Paulo (1599?1884): contribuição ao estudo da assistência social no Brasil. São Paulo, Conselho Estadual de Cultura, 1976, p. 27. 
pósito de legitimar seu poder e domínio. Segundo Fortunato de Almeida, inúmeros fatores concorreram para o incremento do número de confrarias em Portugal nesse período, cabendo destacar, pelo menos, dois deles: a elevada mendicância e o desemprego, decorrentes do grande número de aventureiros frustrados das empresas marítimas, dos "retornados" de expedições militares e da decadência da agricultura; assim como o aumento do número de viúvas, órfãos e parentes desamparados de aventureiros que ficavam no ultramar, daqueles que morriam nas empresas marítimas e/ou nas expedições militares, a ex-agricultores ou, finalmente, aos inválidos das empresas e expedições (3). Pragmaticamente, o Estado não buscou atacar as causas dos problemas sociais, mas sim criar e incentivar mecanismos que combatessem os efeitos.

A rápida proliferação das irmandades da Misericórdia, na Metrópole e depois nas colônias, pode ser caracterizada pela importância que elas adquiririam na vida social dos povos. Basta lembrar, como o fez Charles Boxer, que, dentre as instituições peculiares do império colonial português "que ajudaram a manter unidas as suas diferentes colônias, contavam-se o senado da Câmara e as irmandades de caridade e confràrias laicas", verdadeiros pilares gêmeos da sociedade colonial portuguesa, desde o Maranhão até Macau, garantias de uma continuidade que circunstanciais governadores, bispos e magistrados não tinham condiçōes de assegurar e que se transformaram em suporte da política centralizadora e absolutista da Metrópole (4).

Para além de seus deveres de caráter espiritual, as Misericórdias se incumbiram, fundamentalmente, dos seguintes campos de atuação: "dar de comer a quem tem fome, dar de beber a quem tem sede, vestir os nus, visitar os doentes e presos, dar abrigo a todos os viajantes, resgatar os cativos e enterrar os mortos" (5). Fica claro que o cumprimento a tais encargos exigia delas uma sólida base econômico-financeira, conferindo-lhes a marca de entidades manipuladoras permanentes de avultadas somas de recursos. Integrar os seus quadros possibilitava não só status e prestígio social, como também acesso a bons negócios e a utilização desses recursos em proveito pessoal. Por isso mesmo, as Misericórdias se pautaram por ter, em seus quadros sociais, as camadas privilegiadas da sociedade colonial, isto é, pessoas que necessariamente estivessem dispostas a dispender recursos para a prática de obras assistencialistas, em especial se se habilitassem a cargos da mesa administrativa, principalmente a tão cobiçada e disputada provedoria. Por essa razão, as Misericórdias adqui-

(3) - Almeida, Fortunato de. História da Igreja em Portugal. Coimbra, Imprensa Acadêmica, 1910/7, t. 3, v. 2, p. 477/9.

(4) - Boxer, C. R. O Império colonial português, trad. port., Lisboa, Edições 70, 1977, p. 305.

(5) - Boxer, C. R. op. cit., p. 320. 
riram traço peculiar ao se transformarem em irmandades predominantemente assistencialistas, aquelas que assumiram o ônus da construção e manutenção de hospitais e da provisão de condições mínimas de sobrevivência da população economicamente carente. $O$ seu lado espiritual ficou em segundo plano, em detrimento do aspecto social.

$E$ bem verdade que, na medida em que desenvolviam e subvencionavam a assistência social aos necessitados, os irmãos da Misericórdia praticavam o catolicismo, justificavam-se socialmente e supunham-se recompensados pelas bênçãos do céu.

Esse panorama sofre consideráveis alterações quando a realidade histórica analisada é a da capitania de Minas Gerais. Durante o período colonial, na região na qual se concentrou a exploração aurífera, têm-se notícias da existência de cinco instituições do gênero. A primeira e mais importante foi a de Vila Rica, criada em meados da década de 30, graças ao espírito filantrópico de Henrique Lopes de Araújo, capitão-mor da ordenança e rico proprietário no distrito de Antônio Dias, que em testamento, confiou ao Senado da Câmara local algumas propriedades residenciais e lavras nas terras minerais, com a condição explícita de que órgão instituísse um hospital nas casas, mantendo-o com o rendimento auferido na exploração das lavras.

Embora com embaraços, o desejo testamentário de Henrique Lopes se realizou: constatada a impropriedade de se instalar o hospital nas casas legadas, logo se obteve de outros benfeitores a compra e a doação de imóveis adequados para aquele fim; o apoio e o empenho junto aos órgãos governamentais e ao Rei foi delegado ao Governador e Capitão-General da Capitania, Gomes Freire de Andrade, entusiasta do novo empreendimento.

Lamentavelmente, pouco se conhece hoje dos primeiros tempos da Santa Casa de Misericórdia da capital da Capitania. Tudo leva a crer que a Câmara não se desincumbiu da missão com o zelo $\Theta$ a eficiência que dela se esperava, pois, contando com o endosso da Corte, sob a alega. ção de administrá-lo, teria incorporado o citado legado ao seu patrimônio: desvirtuando o louvável propósito do doador.

A documentação que é dada a conhecer na atualidade contém um longo hiato e os próximos eventos conhecidos da benemérita irmandade datam dos últimos anos do século e dizem respeito, seja aos assentos de um "novo" livro de admissão de irmãos, seja ao juízo pouco lisonjeiro que dela faziam os seus contemporâneos (6).

(6) - "Irmãos da Santa Casa". In: Anuário do Museu da Inconfidência. Ouro Preto, MEC/DPHAN, 1955/1957. v. 4, p. 99/112. A respeito da opinião dos coevos, vide Saint-Hilaire, Auguste de. Viagem pelas Províncias do Rio de Janeiro 
Durante aqueles sessenta anos, parece que foram permanentes as dificuldades da Santa Casa de Vila Rica, que seu patrimônio não cresceu e que sua situação financeira foi sempre precária, porque mamposteiros e esmoleres autorizados a circular pela Capitania para recolher auxílios pecuniários para a obra pia da Misericórdia vilariquense agiam muito mais por espírito caritativo do que para gozarem de privilégios que, rotineiramente, se concediam para situações análogas.

Naquele período, suas condições de atendimento deixavam muito a desejar, a tal ponto que o próprio Governador da Capitania, o Conde de Valadares, escrevendo ao Conde de Oeiras, em 5 de fevereiro de 1769, informava-lhe que "o Hospital da mesma Mizericordia hé tão indigno que só a abitação delle hé cauza bastante para a morte dos Enfermos". Por isso mesmo, para além dos citados mamposteiros e esmoleres, propunha que a Metrópole concedesse à Santa Casa de Misericórdia o rendimento das miunças de Vila Rica (7).

Em Mariana, ou, mais exatamente ainda nos tempos da Vila do Ribeirão do Carmo, algumas evidências documentais fazem pressupor a existência ou, quando menos, o prenúncio de um embrião da Santa Casa de Misericórdia, constituído pelo estabelecimento de um hospital. Assim, em 1736, a Irmandade de Santana peticionava ao Rei solicitando-lhe es mola para continuação da obra de uma casa "em que se possão recolher e curar os enfermos pobres" (8).

Tudo indica que o projeto se tornou realidade, pois, no testamento do Padre Matias Fernandes Afonso, datado de 7 de julho de 1744, este fazia menção a certas casas "que eu fiz a minha custa para o hospital da dita Senhora e para assistencia dos medicos, boticarios, surgiões e religiosos" (9). Além disso, e para tanto, designava, Luís Alves da Gama para a "obrigação de assistir e servir o hospital e buscar quem peça para elle como procurador". Deixava ainda "as últimas casas de sobrado com todos os seus pertencentes... para morarem nellas medicos, e Minas Gerais, trad. port. Belo Horizonte, Itatiaia; São Paulo, EDUSP, 1975,
p. 72/3.

(7) - Arquivo Histórico Ultramarino, de Lisboa (AHU) - Minas Gerais, Documentos Avulsos, Caixa 51.

(8) - AHU. Minas Gerais. Doc. Avulsos. Caixa 15 (22/nov./19736). Não se conhece a decisão final, mas sabe-se que tanto o Provedor Real na Comarca, como o Governador da Capitania emitiram pareceres favoráveis à pretensão (cf. AHU, Minas Gerais., Docs. Avulsos, Caixa 88).

(9) - Trindade, Côn. Raymundo. Instituiçôes de Igrejas no Bispado de Mariana. Rio de Janeiro, Ministério da Educação e Saúde, 1945. (Publicações da DPHAN, 13) . p. 159/60. O orago do hospital citado é Santana. No hospital, à época, havia uma irmandade da mesma invocação, que também foi contempladá neste mesmo testamento. 
surgião e boticarios nas logeas por baixo das mesmas casas por terem capacidade para tudo" (10).

Situação muito semelhante se encontra em São João Del-Rei. Sabese que, em 1769, ainda era a Irmandade de São Miguel e Almas quem fazia as vezes de Misericórdia, contratando cirurgião e boticário para cuidarem de enfermos pobres, mesmo "que não sejão Irmãos desta Irmanndade" (11). Quando nada, pode-se falar na existência de uma "cạsa de hospital e caridade", como era habitual então.

Catorze anos depois, Manuel de Jesus Fortes solicitava ao Bispo de Mariana licença e provisão para usar altar portátil, a fim de celebrar ofícios religiosos para "os enfermos e pessoas que se achassem no Hospital que ele fundou na vila de S. João" (12). Finalmente, em 31 de outubro de 1816 , uma provisão régia confirmava sua fundação e, a partir de janeiro do ano seguinte, a Santa Casa de Caridade passou a se intitular formalmente Santa Casa de Misericórdia de São João Del-Rei (13).

Em Sabará, a Santa Casa tem suas origens no "Vínculo do Jaguara", rico conjunto de fazendas, instituído em 1787 pelo negociante Antônio de Abreu Guimarães e que, com a confirmação régia e sob a administração de seu sobrinho Francisco de Abreu Guimarães, se destinava intransferivelmente a manter, com seus rendimentos, dois estabelecimentos de ensino e um hospital de caridade em propridades do doador.

A tardia instalação da $1^{\text {a }}$. Junta Governativa, aliada à posterior lenta batalha judicial entre o seu administrador e os credores do Vínculo, não apenas abalou a integridade do patrimônio deixado pelo instituidor, como também criou sérias dificuldades financeiras para a Ordem Terceira de Nossa Senhora do Carmo, da Vila de Sabará, a quem foi atribuída, pelo próprio Antônio de Abreu Guimarães, a tarefa de gerir a mencionada casa de caridade. Somente em maio de 1812 é que c hospital foi aberto, vivendo sempre às voltas com a insuficiência de recursos, em virtude da reduzida parcela que lhe fora destinada e do seu inconstante pagamento pela administração do Vínculo.

(10) - Trindade, Côn. Raymundo. idem, ibid.

(11) - $2^{\circ}$ Livro de Entradas de Irmãos da Irmandade de São Miguel e Almas. 1740/1777. fls. 150 v. Apud: Augusto Viegas. Notícia de São João Del Rei. Belo Horizonte, Imprensa Oficial, 1942. p. 104.

(12) - Livro de Acórdãos da Santa Casa da Misericórdia, 1778/1783, fls: 176, apud: Viegas, Augusto. op. cit., p. 103.

(13) - Cintra, Sebastião de Oliveira. Efemérides de São João Del Rei. São João Del Rei, Ed. do Autor, 1967, v. 2, p. 186/7. 
Quanto à Santa Casa do Arraial do Tejuco, o testamento de SaintHilaire é suficientemente eloqüiente e esclarecedor. Assim relatou aquele viajante: "Aí por 1787 um eremita, tendo excitado a caridade dos fiéis, reuniu esmolas muito abundantes para fundar um hospital. Ele adquiriu uma casa em um local muito arejado e dotou o estabelecimento dos objetos necessários. O eremita esmolava; ele estimulava o orgulho dos habitantes e o hospital durou enquanto seu fundador permaneceu no Tijuco. Mas esse útil cidadão, tendo-se aborrecido com certos atos das autoridades locais, retirou-se; as esmolas tornaram-se menos abundantes e o hospital foi abandonado. Aqui é mais difícil que na Europa fundar estabelecimentos de beneficência capazes de subsistir muito tempo. Sustentados por donativos diários, tais estabelecimentos devem ter vida precária" (14).

Ora, o quadro acima delineado mostra uma realidade peculiar em pelo menos, dois aspectos: primeiramente não pode passar despercebido que a quase totalidade das instituições citadas se constituíram como Casas de Caridade e não como Santas Casas de Misericórdia (15) em segundo lugar, que, embora a quantidade de instituições seja relativamente elevada se analisadas em relação à extensão espacial que abrangiam, o papel social e a presença histórica delas foram bastante pobres se comparadas às suas congêneres metropolitanas e litorâneas brasileiras.

Todavia, a inferência de maior relevância histórica que se pode tirar desse quadro é a de que o advento dessas instituições de assistência pública em Minas Gerais se processa coincidentemente com momentos em que a crise sócio-econômica na atividade mineratória se torna mais acentuada. Semelhantemente ao ocorrido em relação à criação da Misericórdia de Lisboa, os problemas sociais gerados pela conjuntura política determinam a implementação de programas assistenciais de caráter imediatista mais intenso.

Aliás, é importante insistir no fato de que, dada a própria natureza e a forma de exploração econômica praticada naquela Capitania, a carência de uma política social se manifestou desde os seus primórdios, permeando todo o setecentos mineiro. A esse propósito, e a título de exemplo, tomem-se algumas áreas nas quais essa falta sobremaneira se evidencia.

(14) - Saint-Hilaire, Auguste de. Viagem pelo Distrito dos Diamantes $e$ Litoral do Brasil, trad. port. Belo Horizonte, Itatiaia; São Paulo, EDUSP, 1974, p. 29.

(15) - As Misericórdias se constituem em associações organizadas, com Compromisso aprovado e confirmado pelas autoridades civis e eclesiásticas competentes, ao passo que as casas de caridade não possuem tal organicidade, sendo, geralmente, anexas a capelas, instituídas e mantidas pela abnegação de uma ou de poucas pessoas. As Misericórdias são obras de esforço e trabalho coletivos, enquanto as casas de caridade são obras individuais e isoladas. 
É o caso, inicialmente, do tratamento e da cura de enfermos, reali. zados em Minas não apenas através de medicamentos oficinais e magistrais, prescritos pelos poucos médicos que lá se estabeleciam, mas tanbém pelo uso de fórmulas caseiras (basicamente originárias de ervas me. dicinais). Acrescente-se a isso, e mormente quando as condições não permitiam o acesso a esses dois tipos, o recurso a práticas de feitiçaria, superstições, preces e penitências como alternativas seja para prevenir, seja para o tratamento.

A expectativa de obtenção de riqueza fácil e imediata parecia anular nos indivíduos qualquer pensamento relativo aos cuidados para com a saúde. Poucos se davam conta da precariedade das condições de saúde pública e da flagrante ausência de saneamento básico nos arraiais e nas vilas. Assim, por exemplo, embora não com a frequiência que as condições locais propiciavam, as Minas Gerais setecentistas se viram às voltas com devastadores surtos epidêmicos, cujo mais conhecido é da influenza ou epidemia de defluxões, que grassou por toda a Capitania, em 1792, determinando, na tentativa de debelá-la, que seus habitantes fossem "obrigados interpuladamente a fazerem fugueiras de ramos e hervas Aromaticas para purificarem o Ar", como apregoava o escrivão da Câmara de Vila do Príncipe (16).

E bem verdade que o recurso à hospitalização é hábito historicamente recente. Normalmente, o tratamento dos enfermos era feito em suas próprias casas, sendo incomum os casos de internação. Por isso, o recurso direto a profissionais da saúde era a praxe na cura dos doentes.

Ainda que através de um cuidadoso levantamento quantitativo dos médicos e cirurgiões que atuaram em Minas Gerais no século XVIII se chegasse a um número expressivo de profissionais, sempre caberia a ressalva de que a medicina então praticada era bastante precária, especialmente em uma área tão inóspita e carente de medicamentos cientificamente produzidos. Bastaria ler algumas páginas do Erário Mineral para se verificar tal fato. Publicado em 1735, este livro foi escrito por Luís Gomes Ferreira, cirurgião e médico português seduzido pela auri sacra fames à região das minas, onde permaneceu durante aproximadamente um quarto de século, ocupando-se simultaneamente com seus negócios (fazendas e mineração) e com a medicina. Em seu alentado tratado, Gomes Ferreira apresenta, com minúcias, as doenças mais comumente encontráveis em Minas Gerais na ocasião, bem como a terapêutica para elas.

(16) - Revista do Arquivo Público Mineiro. Ouro Preto, jan./mar. 1897, $\mathrm{n}^{92}$, fasc. 1, p. 6. Uma rica amostragem descritiva e quantificada das doenças e obitos, com as "causas mortis" pode ser encontrada em Costa, Iraci Del Nero da. Vila Rica: População (1719-1826). São Paulo, IPE-USP, 1979. (Col. Ensaios Econômicos, 1), p. 112/9. 
Sem desconsiderar os reconhecidos méritos dos conhecimentos cien. tíficos do autor, é fundamental salientar a atenção que ele conferiu aos empíricos medicamentos "caseiros", particularmente àqueles consagrados pela cultura indígena, preservados e divulgados na região pelos paulistas. $\mathrm{E}$, no caso, o autor não apenas registra a existência desses métodos de tratamento, como também testemunha sua eficácia.

A carência numérica aliada à discutível competência dos médicos e cirurgiōes existentes em Minas Gerais criava espaço neste campo para a entrada e a atuação de pessoas que se credenciavam para também se exercitar em atividades médicas. Submetendo-se a exames junto às Câmaras, esses "práticos", muitos deles negros forros, podiam obter cartas de habilitação que os autorizassem a sangrar, a sarjar, a lançar ventosa e sanguessugas e a arrancar dentes. Outras ainda, especialmente "pretas velhas", se habilitavam às "cartas de usança de parteira". Sem falar em um número de "botiqueiros"” herbolários e enfermeiros.

Todos esses "profissionais" da medicina tinham à sua disposição um amplo mercado de trabalho, em especial pelos serviços prestados às expensas dos Senados das Câmaras e das irmandades, confrarias e ordens terceiras. Foi praxe no período colonial que as Câmaras contratassem os chamados cirurgiões e médicos "de partido", para o atendimento e a assistência aos presos pobres da cadeia, bem assim para fornecer-lhes remédios. E bem verdade que, através do Contrato das Taxas da Cadeia, o Senado procurava ressarcir-se das despesas realizadas com os encarcerados. Ao contratador, era delegado o direito de cobrar taxas de prisão, em troca dos serviços de manutenção da carceragem. Além disso, os prisioneiros, quando tinham posses, eram, eles mesmos, os responsáveis pelo pagamento dessas despesas; se escravos, cabiam aos respectivos senhores os encargos financeiros para com o seu sustento. Entretanto, pode-se deduzir que o encargo maior acabava sendo atribuído às finanças do Senado, mesmo porque o referido contrato não tinha fácil aceitação junto aos candidatos a arrendatários, se comparados aos demais contratos licitados periodicamente. Ao invés de fonte de rendimento para as Câmaras se transformavam em consideráveis ônus.

Nas irmandades, confrarias e ordens terceiras, a assistência médica a seus membros levava-as a ter e manter permanentemente um corpo de médicos, cirurgióes e enfermeiros e, em certos casos, boticas próprias. É farta a documentação a respeito.

Afora especificamente a área da saúde, outro setor de precário atendimento social na capitania de Minas Gerais foi o dos enjeitados. Praticamente, em todas as partes do vasto império lusitano, cuidar de recém-nascidos abandonados foi uma tarefa de responsabilidade das Misericórdias. O costume era que as Câmaras, mediante o pagamento 
de subvenções, confiassem às Santas Casas esse serviço. Em Minas, na falta delas, coube aos Senados assumir o encargo. Aliás, há que salientar que, por lei, eram esses órgãos os responsáveis pelos destinos dos enjeitados - ditos "expostos" - até que atingissem a idade de sete anos. Para tanto, desde a sua entrega, a Câmara deveria lavrar termo de assento e aceitação da criança em livro próprio e, após essa "matrícula" e o batismo, encaminhá-la, mediante contrato, a casais honrados e de conduta ilibada ou a negras forras e mulatas livres.

Esses contratos, da parte da Câmara, estabeleciam o compromisso do pagamento de mensalidades às "amas-de-leite", em troca do trabalho de cuidar e educar a criança, apresentando-a periodicamente àquele orgão.

E correto supor, porém, que tais contratos fossem desrespeitados por ambos os celebrantes. A Câmara, por não efetuar os pagamentos com a periodicidade e regularidade estipuladas; as "amas-de-leite" e os casais, por nem sempre cumprirem suas efetivas atribuições e tarefas, de que dão conta o elevado número de óbitos e contínuas acusações de maustratos e abandono dos menores.

De todo modo, esse tipo de atendimento aos enjeitados se fez constante por todo o período. Fique claro, no entanto, que a questão em pauta não diz respeito ao ônus financeiro desse atendimento social. $O$ ônus era, inquestionavelmente, das Câmaras. O que se destaca é que, em Minas Gerais, coube a esses órgãos cuidar do próprio atendimento, imiscuindo-se em setor que, nas outras partes, a contragosto ou não, foi assumido pelas Santas Casas de Misericórdia.

Por outro lado, se bem que as Câmaras tenham se responsabilizado pelas crianças enjeitadas, cabe assinalar que só muito tardiamente elas cuidaram de estabelecer uma roda de exportos (17). Quando as dificuldades econômicas geradas pelo declínio e decadência da atividade mineradora se acentuaram, intensificou-se a crise social e, como parte dela, aumentou enormemente o número de enjeitados. Daí, e só então é que surgiram propostas compatíveis com a gravidade do problema. O século XVIII estava em seu último lustro quando se propôs a criação de uma roda em Vila Rica. Até então, os enjeitados faziam jus à conotação estrita do termo, pois eram deixados pelos seus pais carnais nos mais diversificados lugares, preferencialmente, e por razões óbvias, nas

(17) - A roda dos expostos em uma Misericórdia, como as dos conventos de outrora, era uma caixa cilíndrica, fechada em um dos lados, sendo incrustrada nas paredes do prédio. O enjeitado era nela depositado, pelo lado de fora do muro e, girando-se a roda para dentro, recolhia-se a criança, mantendo, assim, o anonimato do responsável pela sua entrega. 
calçadas, nos logradouros públicos, nas portas das casas e/ou no interior das igrejas. Não havia, antes, um local único e apropriado, como a sugerir a inexistência desse problema social ou de que a obrigação de cuidar do recém-nascido coubesse essencialmente ao espírito caritativo de determinadas pessoas. Por isso, não é difícil pressupor, de um lado, que expressivo número de crianças abandonadas tenha morrido antes de serem encontradas e entregues às Câmaras; de outro, que muitas delas tenham ficado irreversivelmente afetadas em sua saúde, vindo a falecer prematuramente, pelo que se lê nos registros encontrados nos livros de matrículas dos enjeitados, existentes nos acervos documentais relativos às câmaras das vilas coloniais .

Em suma, não há dúvida de que, avocando para si mesmo, ou, como de regra ocorreu, confiando a responsabilidade pelos enjeitados a particulares e não às Santas Casas, os Senados das Câmaras davam uma inequívoca demonstração de suspeita relativamente ao atendimento e aos serviços prestados por aquelas instituições. Ao mesmo tempo, com tal atitude, evidenciavam a desconsideração e o desprestígio das Misericórdias no interior da sociedade mineira colonial.

O panorama que se está esboçando, por todos esses exemplos, parece demonstrar que os problemas sociais estavam fortemente presentes na realidade histórica em estudo. Todavia, sem ter a ingenuidade de aprofundar-se na matéria, torna-se necessário sair do campo das evidências empíricas e tentar compreender e explicar, aventando outras razões que justifiquem o alegado insucesso e a presença secundária das Santas Casas de Misericórdia na Capitania do Ouro.

De imediato, é preciso destacar que, em praticamente todo o império português, as Misericórdias se sustentavam econômica e financeiramente às custas de recursos oriundos de particulares, isto é, foram obra da piedade individual. O Estado incentivava, colaborava, concedia privilégios e regalias, mas não tomava a iniciativa e muito menos assumia a responsabilidade dos encargos financeiros da empresa. A criação e manutenção dessas instituições estiveram sujeitas a atos de caridade e solidariedade mútua coletiva ou individual.

Especificamente, o sustentáculo básico das Santas Casas de Misericórdia eram os legados e as doações obtidas através de testamentos e inventários, via de regra, constituídos por bens alienáveis. A alienação dos mesmos gerava capital que era aplicado em empréstimos a juros, de cuja renda se retiravam os recursos necessários às obras caritativas daqueles sodalícios, como também, às vezes, para o pagamento das despesas com o funeral e o enterro do doador ou legatário e para a celebração de missas pela sua alma ("sufrágios"). 
Já em Minas Gerais, os bens testamentados beneficiavam principalmente os próprios familiares do testador ou as irmandades a que este pertencera. Quanto à administração dos referidos bens, nem sempre aquelas associações puderam tirar real proveito dos mesmos, pois os documentos de legados e doações invariavelmente vinculavam e prescreviam os gastos a serem com eles efetuados, os quais, em última análise, beneficiavam o próprio irmão doador ou legatário, na medida em que os bens deixados se destinavam a arcar com as despesas decorrentes do enterro e sepultamento dessas pessoas e com as incontáveis missas votivas e sufrágios, pouco restando para as obras sociais caritativas.

Se, no geral, o espírito que presidiu a criação das Misericórdias foi o da caridade cristã, ou seja, o amparo ao próximo como forma concreta de manifestação de amor do fiel a Deus, tal não se verificou na capitania de Minas Gerais. A ética da prática religiosa dos mineiros parece ter sido outra. Grosso modo, poder-se-ia afirmar que o cristão habitante daquela área levava ao pé-da-letra o ensinamento dos Evangélhos: amar a todos irmãos significava amar seus 'irmãos', isto é, seus confrades nas irmandades. Com fortes traços de individualismo e egocentrismo, o espírito de solidariedade cristã dos mineiros se esgotava no estreito limite alcançado pelos familiares dos indivíduos (se os possuía) ou nas suas próprias pessoas. Daí porque a problemática ora em análise reclama o estudo da mentalidade do homem mineiro colonial.

Retomando-se a questão financeira, é preciso observar também que a exploração aurífera não determinou o aparecimento de um número expressivo de homens ricos na Capitania. Segundo Fritz Teixeira de Salles, "o viver desta gente foi viver de pobre, foi uma sagacidade permanente que não conheceu, jamais, a doce tranquilidade das abundâncias perenes ou estabelecidas em sólida economia sem susto nem surpresa. Na Minas da mineração nada foi jamais suave" (18). Com isso, reduzia-se o círculo daqueles que, em outras paragens, se constituíam em potenciais ocupantes das funções de provedores nas associações caritativas. Em Minas, como já se disse, foram raros os casos de filantropos. De sua parte, no que lhes competia, com poucas exceções, os governadores da Capitania não se empenharam junto à Metrópole no sentido de obter autorização para a circulação de esmoleres na região. Enquanto em outras capitanias, como na de São Paulo, os esmoleres tiveram privilégios e isenção de serviço militar (19), nas Minas Gerais o que se sente é a existência de uma legislação rigorosamente proibitiva a respeito. Bastaria

(18) - Salles, Fritz Teixeira de. Associações Religiosas no Ciclo do Ouro. Belo Horizonte, UMG/Centro de Estudos Mineiros, 1963. (Col. Estudos, 1). p. 112.

(19) - Mesgravis, Laima. op. cit., p. 210. 
citar, a título de ilustração, a Carta Régia endereçada ao Bispo de Mariana, em 22 de fevereiro de 1755, pela qual se ordenava ao prelado que não mais consentisse na manutenção, em Vila Rica, de um hospício construído pelos Irmãos da Caridade e Filhos da Divina Providência, que se destinava a "nelle instalarem e se occuparem em pedir esmollas para com ellas acudirem aos enfermos prezos, e mais necessidade desses Povos" (20).

Adicione-se a tudo isso, e intimamente interligado a ess últmio motivo, o fato de que a proibição de fixação de ordens religiosas em Minas Gerais, durante a fase colonial, também desfavoreceu o surgimento e a consolidação das Misericórdias naquela Capitania. Não que as Santas Casas fossem obra a ser creditada a religiosos regulares ou seculares, mas sim porque estes, em grande parte, foram e ainda hoje são os responsáveis pelo ministério das obras assistenciais prestadas pelas Misericórdias.

Os fatores até aqui apontados fazem convergir para o âmbito das demais irmandades mineiras leigas a maior fração do assitencialismo praticado na região, cabendo relembrar sua característica fundamental, qual seja, a de que essas outras agremiações eram muito mais abertas e permeáveis à admissão de novos adeptos. Elas "basicamente têm regras semelhantes às das Misericórdias, procuram, entretanto, promover o benefício dos próprios membros, sem tentar favorecer pessoas estranhas ao grêmio. Não se dedicam aos enfermos e presos, mas, em verdade, tentam desenvolver a vida social e religiosa de seus associados" (21). Nesse sentido, se bem que as irmandades das Misericórdias assistissem a todos os necessitados, independentemente de sua situação de classe, credo cu cor, não deixavam também de ser restritivas quanto à composição de seu quadro de associados, pois filiar-se a elas exigia do candidato certos requisitos, como o da pureza de sangue e o de uma relativa disponibilidade de dinheiro para as obras assistenciais coletivas; o insucesso dessas associações em Minas Gerais vem reforçar a tese do acentuado exclusivismo confrarial existente na regiáo (22).

A destacar, também, o fato de que, em Minas, as Santas Casas surgiram muito tardiamente. Por isso, na sua ausência, ou mesmo como fator inibidor ou neutralizador ao seu advento, é que determinadas irmandades,

(20) - Arquivo Eclesiástico da Arquidiocese de Mariana (AEAM). Livro de Registro de Cartas, Provisões, Ordens e Alvarás Régios do Bispado de Mariana $(1752 / 1822)$. fls. $25 \mathrm{v}$.

(21) - Scarano, Julita. Devoção e escravidão; a Irmandade de Nossa Senhora do Rosário dos Pretos do Distrito Diamantino no século XVIII. São Paulo, Nacional, 1976, p. 28.

(22) - Boschi, Caio C. Estado e Irmandades em Minas Gerais no século XVIII. São Paulo, 1982. mimeo. (Tese de Doutoramento no Departamento de História da FFLCH/USP). 
como as da invocação do Santíssimo Sacramento, de São Miguel e Almas e das Almas, especialmente estas últimas, passaram a reivindicar o monopólio e o privilégio dos enterros concedidos às Misericórdias. Vale dizer que, para além do compromisso estatutário de sepultar seus próprios irmãos, elas se apresentavam como ofertantes monopolistas dos serviços funerários para não-irmãos, seja cobrando por esses serviços, seja executando-os por caridade.

Para se compreender melhor o que isto significava na sociedade mineira colonial é mister destacar que, na mentalidade do homem da época, a garantia da sobrevivência da alma ao lado da pompa e circunstância do ritual de sepultamento faziam da atitude diante da morte uma das preocupações dominantes. Nessa medida, pensava-se que 0 instrumento de obtenção e alcance daqueles desejos era o ingresso nas numerosas e hagiograficamente variadas associações leigas ali existentes. Significa dizer que participar de uma ou mais irmandades tornava-se condição de vida e de morte para o habitante das Minas. Como afirma José da Paz Lopes, "era importante e necessário ser 'irmão' de uma Irmandade qualquer. A entrada na Confraria representava a fuga à marginalização. $\mathrm{Na}$ 'profissão' o indivíduo, se bem nascido, encontrava a projeção desejada; se mal nascido, a alienação, o lenitivo ou a ilusão. Depois de morto, pertencer a uma corporação religiosa era uma necessidade, pois, do contrário, Minas lhe negava a terra. Não havia enterro sem o hábito de 'Irmão' "' (23).

Cumpre notar, porém, que a admissão nesses grêmios nem sempre era fácil e tranquiila. Os doentes, idosos e agonizantes tinham o seu acesso aos quadros das irmandades enormemente dificultado, principalmente pela cobrança de avultadas taxas de entrada. Por exemplo, a Irmandade de São Miguel e Almas, da freguesia de Nossa Senhora da Piedade, do Arraial da Igreja Nova da Borba do Campo, declarava explicitamente em seu Compromisso, no capítulo 1, quanto à taxa de entrada: "até a idade de quarenta anos, mil e duzentos réis; e os que excederam a esta idade, o que se ajustar"' (24).

Assegurar em vida um lugar para $o$ descanso final era fundamental. A garantia do sepultamento parece ter sido uma verdadeira obsessão por

(23) - Lopes, José da Paz. "Uma corporação religiosa: vida e obra da Venerável Ordem Terceira de Nossa Senhora do Monte do Carmo da Vila de São João Del Rei"', Revista de História, São Paulo, 46 (93): 97-113, jan./mar., 1973, p. 99.

(24) - AEAM. Compromisso desta Irmandade. 1785, cap. 1, fls. 2. A esse respeito, consulte-se também idêntica diretriz por parte da Ordem Terceira de Nossa Senhora do Carmo, de Sabará. (cf. Passos, Zoroastro Vainna. Em torno da História do Sabará. Rio de Janeiro, Ministério de Educação e Saúde, 1940. (Publicação da SPHAN, 5). v. 1, p. 25 e 94, referentes aos Termos da Mesa de 29/3/1762 e 27/2/1762, respectivamente). 
parte das populações mineiras coloniais. Praticamente só aqueles indivíduos que se filiassem a uma irmandade tinham a referida garantia, pois os cemitérios se localizavam nos terrenos das irmandades, quase sempre dentro dos próprios templos, mediante o estabelecimento de um certo número de sepulturas que lhes eram concedidas pelas autoridades eclesiásticas. Esse costume perdurou até janeiro de 1801 , quando uma carta régia proibiu os cemitérios dentro das igrejas. Verifica-se, no entanto, que essa determinação legal, como muitas outras a esse mesmo propósito, foi amplamente desrespeitada. Tanto assim que, quase trinta anos depois é que se construíram em Minas Gerais os primeiros cemitérios públicos localizados fora dos templos, não sem gerar graves protestos e grandes resistências da população.

Logo se vê que em Minas Gerais os serviços fúnebres, diante da apontada lacuna das Misericórdias, eram objeto de disputa entre as irmandades, pois se constituíam em uma atividade que rendia não só enorme prestígio junto à comunidade, como bons ganhos pecuniários, devidos ao aluguel de tumbas e esquifes ou mesmo pelo simples acompanhamento e cortejo.

E fácil perceber, sem querer negar o caráter assistencialista, que se tratava de uma prestação de serviços extremamente lucrativa e uma excelente fonte de receita para a irmandade privilegiada, isto é, aquela associação que, dada a ausência das Santas Casas, era credenciada pelas autoridades civis e eclesiásticas par esse tipo de atendimento. Não é por acaso que em Minas proliferaram irmandades sob a invocação das Almas ou de São Miguel e Almas, para as quais se transferiam, por direito, todos os privilegiados reais concedidos às Misericórdias em lugares onde essas não existissem. E, talvez, esse seja mais um fator inibidor do florescimento das Misericórdias em Minas.

Cabe assinalar, por fim, que tais concessões e privilégios, cujo mais conhecido é o do uso das tumbas nos enterros, não eram letra morta, mais sim direito efetivamente reivindicado e preservado com vigilância e zelo por aquelas associações. Se de um lado as mencionadas irmandades das Almas e de Soã Miguel e Almas tinham privilégios, de outro, näo se nega que elas assumiam o compromisso de acompanhar e enterrar os fiéis pobres e desamparados. Contudo, o número de pleitos judiciais èm que elas se envolveram na disputa de tais prerrogativas é hoje o melhor atestado da relevância que atribuíam à questão: seja pelo prestígio que conferia, seja pelos resultados financeiros que oferecia, seja por ambas as razões.

Em resumo, pode-se concluir que na realidade colonial mineira as funções assistencialistas ficaram a cargo dos Senados das Câmaras e das associações leigas, dentre as quais, naquela região, não se destacaram 
as Santas Casas de Misericórdias. Ali elas foram substituídas pelas demais irmandades, confrarias e ordens terceiras. Dadas a voluntária omissão do Estado e a legislação cerceadora da presença de clérigos e, em especial, de ordens religiosas na Capitania, foi no interior dessas associações que os habitantes da região encontraram ajuda espiritual e material. Mesmo quando o Estado acentuou sua presença $\theta$ se consolidou em Minas Gerais, elas não perderam as suas funções sociais. Antes, solidificaram-nas. Com isso, ainda que possa parecer paradoxal, indiretamente essas agremiações atendiam aos interesses do Estado, na medida em que este lhe transferia o encargo de certas obrigações essenciais ao convívio social, particularmente aquelas relativas ao assistencialismo. Com tal comportamento, as irmandades aliviavam o Estado da onerosa responsabilidade social para com seus súditos e, ao mesmo tempo, se integravam e passavam a se constituir em um dos instrumentos básicos da política colonizadora portuguesa para a área mineradora. 